\title{
POLIKULTUR RUMPUT LAUT, Gracillaria sp. DAN IKAN BANDENG, Chanos chanos DENGAN PADAT PENEBARAN YANG BERBEDA
}

\author{
Muhammad Tjaronge
}

\begin{abstract}
ABSTRAK
Penelitian bertujuan untuk menentukan kepadatan bandeng yang optimal untuk peningkatan produksi rumput laut, Gracillaria sp. di tambak. Penelitian diawali dengan melakukan persiapan tambak sebanyak 9 petak masing-masing berukuran luas $2.500 \mathrm{~m}^{2}$. Percobaan disusun dalam Rancangan Acak Lengkap (RAL) dengan ulangan sebanyak 3 kali. Benih rumput laut ditebar sebanyak $250 \mathrm{~kg} /$ petak, kemudian diberi perlakuan yaitu perbedaan padat penebaran ikan bandeng sebanyak: $A)=500, B)=1.000$, dan $C)=1.500$ ekor/petak. Pengamatan terhadap pertumbuhan rumput laut, pertumbuhan bandeng, kualitas air, dan tanah, serta kandungan agar rumput laut dilakukan setiap 15 hari, sedangkan produksi rumput laut ditentukan setiap 45 hari setelah pemeliharaan. Hasil riset menunjukkan bahwa pertumbuhan rumput laut pada pemeliharaan 45 hari pertama tidak berbeda pada setiap perlakuan. Total produksi rumput laut setelah pemeliharaan 45 hari pertama lebih tinggi pada perlakuan $A$ dan berbeda dengan perlakuan $B$ dan $C$, sedangkan pada pemeliharaan 45 hari kedua, produksi pada ke-3 perlakuan tidak berbeda. Nilai rataan bobot dan panjang rataan bandeng tidak berbeda antar ke-3 perlakuan. Kisaran nilai kualitas air dan tanah layak untuk pertumbuhan rumput laut dan bandeng, kecuali salinitas yang mencapai $45 \mathrm{ppt}$ rumput laut masih dapat hidup. Kisaran kandungan agar rumput laut tidak berbeda antar ke-3 perlakuan. Hasil riset dapat disimpulkan bahwa pemeliharaan rumput laut dengan penebaran $250 \mathrm{~kg} / 2.500 \mathrm{~m}^{2}$ yang dibudidayakan secara polikultur dengan penebaran gelondongan bandeng sebanyak 500 ekor $/ 2.500 \mathrm{~m}^{2}$ akan memberikan produksi rumput laut yang lebih tinggi dibandingkan dengan padat penebaran 1.000 dan $1.500 \mathrm{ekor} / 2.500 \mathrm{~m}^{2}$.
\end{abstract}

\section{ABSTRACT: Policulture of seaweed, Gracillaria sp. and milkfish, Chanos chanos on different densities. By: Muhammad Tjaronge}

The aim of this research is to study the optimal density of milkfish to increase production of seaweed, Gracillaria sp. in the 9 brackishwater ponds having the dimension of $250 \mathrm{~m}^{2}$ each. The brackishwater ponds were set up in a completely randomized desaign to facilitate 3 treatments consisting of 3 replicates each. The treatmens is density of milkfish, namely: A) 500, B) 1,000, and C) 1,500 ind/pond. The seaweed seed planted $250 \mathrm{~kg} / \mathrm{pond}$. The observation of seaweed and milkfish growth, water and soil quality were carried out every 15 days. The harvest of seaweed was done every 45 days. The growth of seaweed at culture of the first 45 days culture was not significantly different $(P>0.05)$ while production of seaweed was significantly different $(P<0.05)$. The hightest production of seaweed in treatment $A\left(250 \mathrm{~kg}\right.$ seaweed and 500 milkfish $/ 2,500 \mathrm{~m}^{2}$, while in the second 45 days culture was not different. Average of the weight and the length of the seaweed among 3 treatments is not different. Meanwhile, the water and soil quality range is suitable for the growth of seaweed and milkfish, except in the salinity up to 45 ppt. However the seaweed is still life around the salinity. The results of the study also showed that among 3 treatments there were thera no differences. Based on that the information, it can be concluded that the seaweed of $250 \mathrm{~kg} /$ $2,500 \mathrm{~m}^{2}$ policultured with milkfish of 500 ind./2,500 $\mathrm{m}^{2}$ will give the production of seaweed higher than that of 1000 and 1500 ind. $/ 2,500 \mathrm{~m}^{2}$.

KEYWORD: $\quad$ seaweed, milkfish, policulture, pond

\section{PENDAHULUAN}

Perkembangan budi daya rumput laut, Gracillaria sp. di tambak tidak secepat komoditas udang yang telah menyebar di hampir semua pertambakan yang ada di Indonesia. Tetapi dengan penyebaran penyakit udang yang melanda semua lahan pertambakan, maka sebagian petambak sudah mengalihkan usahanya ke komoditas rumput laut sebagai alternatif budi daya yang relatif tidak berisiko. Selain itu harga rumput laut di pasar lokal maupun internasional terus membaik sehingga dapat menguntungkan petani. 
Harga yang semakin membaik ini juga disebabkan oleh permintaan pabrik agar-agar dalam negeri dan ekspor bahan baku yang terus meningkat. Sejak tahun 2001 rumput laut sudah menjadi komoditas ekspor urutan ke-6 setelah ikan hias, kodok, kepiting. tuna, dan udang (Ditjen Perikanan Budidaya, 2004) dan secara ekonomi memberikan sumbangan devisa bagi negara (Susanto \& Mucktiny, 2004; Aslan, 1995; Afrianto \& Liviawaty, 1989).

Permintaan rumput laut yang tinggi disebabkan oleh pemanfaatannya yang multi guna, antara lain untuk industri makanan, farmasi, kedokteran, kosmetik, dan kertas (Sadhori, 1989; Wong \& Cheung, 2000; Soegiarto et al.,1978)

Menurut Soegiarto et al. (1978) potensi pengembangan budi daya rumput laut Gracillaria sp. di tambak yang berdekatan dengan laut diperkirakan seluas 9.000 ha atau $2 \%$ dari luas areal tambak di Indonesia yang mencapai 450.000 ha. Beberapa negara yang merupakan pangsa pasar rumput laut yang menggiurkan yaitu: Hongkong, Korea Selatan, Perancis, Inggris, Kanada, Amerika Serikat, Jepang, dan lain-lain, memacu negara penghasil rumput laut seperti Indonesia untuk meningkatkan produksinya yang pada gilirannya meningkatkan devisa negara. Sukmadinata (2001) melaporkan bahwa ekspor rumput laut tahun 2000 mencapai 23.073.411 ton dengan nilai US\$15.670.498

Di Sulawesi Selatan, pertambahan bobot dan produksi bibit rumput laut dari Kabupaten Luwu lebih baik jika dibandingkan dengan yang dari Kabupaten Takalar dan Sinjai (Tjaronge \& Pong-Masak, 2003) Bahkan dari aspek kualitas merupakan yang terbaik kedua di dunia setelah Chili (Saad, 2004). Selain kandungan agar, kualitas produksi rumput laut kering juga sangat dipengaruhi oleh kebersihan termasuk keberadaan lumut.

Beberapa peran kehadiran bandeng dalam polikultur dengan rumput laut antara lain dapat membersihkan rumput laut yang ditempeli oleh kelekap dan lumut dengan cara memakan kelekap dan lumut tersebut. Pada budi daya rumput laut, biasanya ditebar bandeng dan udang secara polikultur yang dimaksudkan untuk mengurangi lumut di dalam tambak, karena keberadaan lumut akan menurunkan kualitas rumput laut kering (Ratnawati \& Mustafa, 2003). Bandeng akan memakan epifit yang menempel pada rumput laut dan akan meningkatkan kualitas rumput laut (Pantjara et al., 2003). Selain itu, bandeng diharapkan juga dapat menimbulkan gerakan air sehingga lumpur yang menempel pada rumput laut dapat terlepas. Akibat lebih lanjut adalah proses difusi unsur hara ke dalam rumput laut lebih meningkat, sehingga pertumbuhan rumput laut dapat lebih baik.
Keberadaan bandeng dalam budi daya rumput laut diharapkan dapat meningkatkan produksi tambak, apabila jumlah bandeng yang ditebar tidak memberikan efek pertumbuhan rumput laut serta penggunaan lahan budi daya yang optimal dan produktif. Penambahan padat penebaran bandeng yang melebihi kapasitas daya dukung suatu lahan tambak diduga akan menyebabkan penurunan produksi rumput laut. Terbatasnya daya dukung suatu lahan tambak, menyebabkan bandeng akan memakan rumput laut terutama tallus yang masih muda apabila ketersediaan nutrien dan pakan dalam tambak sudah berkurang. Oieh karena itu perlu diketahui kombinasi kepadatan yang optimal antara rumput laut dan bandeng dalam sistem polikultur di tambak.

\section{METODOLOGI}

Penelitian ini dilakukan di Tambak Percobaan Balai Riset Perikanan Budidaya Air Payau, Maros. Tambak percobaan sebanyak 9 petak masing-masing seluas $2.500 \mathrm{~m}^{2}$ (ukuran $25 \times 100 \mathrm{~m}^{2}$ ). Sebelum digunakan, terlebih dahulu dilakukan persiapan tambak yang meliputi: perbaikan pematang, pembuatan caren, saluran pemasukan dan pengeluaran air, pengeringan tambak, pengapuran, serta pemberantasan hama. Pengapuran dasar tambak dan dinding pematang dilakukan dengan dosis $2.000 \mathrm{~kg} / \mathrm{ha}$ sedangkan pemberantasan hama dengan menggunakan saponin. Pemupukan awal menggunakan urea dan TSP dengan perbandingan $2: 1$ sebanyak $200 \mathrm{~kg} / \mathrm{ha}$ dan dilakukan pemupukan susulan setiap 15 hari sebanyak 10\% (20 $\mathrm{kg} / \mathrm{ha}$ ) dari dosis pemupukan awal dan dilakukan selama penelitian berlangsung. Pengisian air tambak dilakukan sampai dengan ketinggian $50 \mathrm{~cm}$ di atas pelataran dan dibiarkan selama 3 hari sebelum penebaran benih

Percobaan dilaksanakan dengan menggunakan Rancangan Acak Lengkap (RAL). Perlakuan yang diaplikasikan adalah padat penebaran gelondongan bandeng yaitu : A) 500 ekor $/ 2.500 \mathrm{~m}^{2}$, B) 1.000 ekor/ $2.500 \mathrm{~m}^{2}$, dan C) 1.500 ekor $/ 2.500 \mathrm{~m}^{2}$, dimana setiap perlakuan diulang sebanyak 3 kali. Benih rumput laut diperoleh dari daerah Palopo, Kabupaten Luwu diadaptasi kemudian ditebar sebanyak $250 \mathrm{~kg} /$ petak secara merata (broadcast method) pada permukaan dasar di setiap unit tambak percobaan

Sampling pertumbuhan rumput laut dan bandeng dilakukan setiap 15 hari. Sampling dilakukan dengan menggunakan timbangan yang mempunyai tingkat ketelitian 0,1 g. Rumput laut yang dijadikan sampel pemantauan pertumbuhan ditempatkan pada titik pengamatan kotak berukuran $2 \times 2 \mathrm{~m}^{2}$ yang terbuat dari bilah-bilah bambu dalam setiap petakan tambak. Setiap petakan tambak terdapat 2 titik kotak 
pengamatan. Sampel rumput laut yang ditebar pada setiap titik kotak pengamatan sebanyak $600 \mathrm{~g}$. Sampling ikan bandeng dilakukan dengan mengukur bobot dan panjang total di setiap petak tambak.

Produksi ditentukan dengan cara menimbang berat total rumput laut setiap petak pada saat panen yaitu setelah pemeliharaan 45 hari (tahap I) dan 90 hari (tahap II). Setelah panen, dilakukan pengeringan total produksi rumput laut setiap petak tambak kemudian ditimbang untuk mengetahui bobot produksi keringnya. Pengamatan kualitas air meliputi: $\mathrm{pH}$, salinitas, DO, BOT, Fe, $\mathrm{SO}_{4}, \mathrm{NO}_{2}, \mathrm{NO}_{3}, \mathrm{NH}_{4}$, dan $\mathrm{PO}_{4}$, sedangkan analisis tanah tambak meliputi: $\mathrm{pH}, \mathrm{BOT}$, $\mathrm{N}, \mathrm{Fe}$, dan fosfat yang dilakukan pada awal dan selanjutnya setiap 15 hari. Kandungan agar dianalisis pada awal penebaran dan selanjutnya setiap 15 hari. Data pertumbuhan dan produksi diestimasi dengan analisis ragam dan diuji lanjut dengan tes Tukey. Data kualitas air dianalisis dan dibahas secara deskriptif.

\section{HASIL DAN BAHASAN}

Pertumbuhan rumput laut pada setiap perlakuan selama penelitian dilaksanakan dapat dilihat pada Tabel 1. Pada pemeliharaan tahap pertama, pertumbuhan rumput laut setiap interval waktu pengukuran antar perlakuan tidak berbeda $(P>0,05)$. Pertumbuhan yang dicirikan oleh pertambahan bobot dari penebaran awal sebanyak $600 \mathrm{~g}$ dan diukur setiap 15 hari, mengalami pertumbuhan yang relatif sama. Kondisi tersebut diduga karena pemeliharaan bibit sebagai sampel pengamatan ditempatkan dalam kotak yang diberi pembatas bilah-bilah bambu, sehingga ikan bandeng yang ditebar tidak secara kontinyu masuk ke dalam kotak pemeliharaan tersebut. Walaupun demikian, pada interval pengamatan hari ke-45 terlihat bahwa secara kuantitatif pertambahan bobot rumput laut pada pemeliharaan tahap I lebih tinggi dibandingkan dengan pemeliharaan tahap II. Hal tersebut diduga disebabkan oleh perbedaan persiapan lahan tambak dimana pada pemeliharaan tahap I, tambak dipersiapkan cukup lama mulai dari pengeringan, pengapuran, pemberantasan hama sampai pemupukan sedangkan pada pemeliharaan tahap II tambak langsung ditebari kembali setelah panen tahap I selesai. Kemungkinan lain adalah terjadinya perubahan kualitas air khususnya salinitas yang semakin tinggi yang mencapai 45 ppt sehingga memperlambat laju pertumbuhan.

Indikator utama yang dinilai sebagai keberhasilan penelitian ini adalah produksi rumput laut. Kisaran produksi rumput laut yang diperoleh pada 2 tahap pemeliharaan pada penelitian ini dapat dilihat pada Tabel 2. Pada pemeliharaan tahap I, perlakuan A diperoleh jumlah produksi yang lebih tinggi dan berbeda dengan jumlah produksi pada perlakuan $B$ dan $C(P<0,05)$, sedangkan pada pemeliharaan tahap II, jumlah produksi yang diperoleh pada ketiga perlakuan tidak berbeda $(P>0,05)$. Berdasarkan hasil yang diperoleh pada pemeliharaan tahap I, maka dapat dikatakan bahwa padat penebaran bandeng mempengaruhi produksi rumput laut, Gracillaria sp. di tambak. Peningkatan jumlah bandeng yang melebihi 2000 ekor/Ha diduga sudah melebihi kemampuan tambak untuk menyediakan pakan dan

Tabel 1. Nilai pertumbuhan rumput laut, Gracillaria sp. dengan padat tebar bandeng, Chanos chanos 500 ekor/2.500 m²; 1.000 ekor/2.500 m²; dan 1.500 ekor/2.500 m² selama penelitian

Table 1. Growth of seaweed, Gracillaria sp. with the to density of milkfish, Chanos chanos 500 individul $2,500 \mathrm{~m}^{2} ; 1,000$ individu/2,500 $\mathrm{m}^{2}$; and 1,500 individu/2,500 $\mathrm{m}^{2}$ during experiment

\begin{tabular}{|c|c|c|c|}
\hline $\begin{array}{c}\text { Waktu sampling (ha ri) } \\
\text { Observations (day) }\end{array}$ & $\begin{array}{l}\text { Perlakuan A }(g) \\
\text { Treatment } A(g)\end{array}$ & $\begin{array}{l}\text { Perlakuan B }(\mathrm{g}) \\
\text { Treatment B }(g)\end{array}$ & $\begin{array}{l}\text { Perlakuan C }(\mathrm{g}) \\
\text { Treatment } C(g)\end{array}$ \\
\hline $\begin{array}{l}\text { Pemeliharaan Tahap I } \\
\text { Stage I }\end{array}$ & & & \\
\hline Awal (Initial) & 600 & 600 & 600 \\
\hline 15 & $896.67^{a} \pm 154.62$ & $766.67^{a} \pm 14.43$ & $1,041^{a} \pm 376$ \\
\hline 30 & $1,583.33^{b} \pm 28.87$ & $1,633.33^{\mathrm{b}} \pm 361.71$ & $1,750^{\mathrm{b}} \pm 433.01$ \\
\hline 45 & $2,016.67^{\mathrm{c}} \pm 202.07$ & $2,250^{c} \pm 1132.48$ & $2,050^{c} \pm 476.97$ \\
\hline \multicolumn{4}{|l|}{ Pemeliharaan Tahap ॥ } \\
\hline Awal (Initial) & 600 & 600 & 600 \\
\hline 15 & $1,145.67^{a} \pm 189.75$ & $908.33^{a} \pm 123.32$ & $1,158.33^{a} \pm 118.15$ \\
\hline 30 & $1,578.33^{b} \pm 49.07$ & $1,100^{b} \pm 563.47$ & $708.33^{b} \pm 513.77$ \\
\hline 45 & $1,650^{c} \pm 132.29$ & $1,633.33^{c} \pm 416.33$ & $2,300^{c} \pm 776.21$ \\
\hline
\end{tabular}


Tabel2. Produksi rumput laut, Gracillaria sp. dengan padat tebar bandeng, Chanos chanos 500 ekor/2.500 $\mathrm{m}^{2} ; 1.000$ ekor $/ 2.500 \mathrm{~m}^{2}$; dan 1.500 ekor $/ 2.500 \mathrm{~m}^{2}$ selama penelitian

Table 2. Production of seaweed, Gracillaria sp. to density of milkfish, Chanos chanos are 500 individu/ $2,500 \mathrm{~m}^{2} ; 1,000$ individu/2,500 $\mathrm{m}^{2}$; and 1,500 individu/2,500 $\mathrm{m}^{2}$ during experiment

\begin{tabular}{|c|c|c|c|}
\hline $\begin{array}{c}\text { Waktu sampling (hari) } \\
\text { Observations (day) }\end{array}$ & $\begin{array}{l}\text { Perlakuan A }(\mathrm{g}) \\
\text { Treatment A }(\mathrm{g})\end{array}$ & $\begin{array}{l}\text { Perlakuan B }(\mathrm{g}) \\
\text { Treatment B }(g)\end{array}$ & $\begin{array}{l}\text { Perlakuan C }(\mathrm{g}) \\
\text { Treatment } C(g)\end{array}$ \\
\hline \multicolumn{4}{|l|}{$\begin{array}{l}\text { Pemeliharaan Tahap I } \\
\text { Stage I }\end{array}$} \\
\hline $\mathrm{A} 1$ & 472 & 283 & 281 \\
\hline $\mathrm{A} 2$ & 438 & 337 & 286 \\
\hline $\mathrm{A} 3$ & 411 & 327 & 368 \\
\hline Rataan (Average) & $440.33^{a} \pm 30.57$ & $315.67^{b} \pm 28.73$ & $311.67^{b} \pm 48.85$ \\
\hline \multicolumn{4}{|l|}{$\begin{array}{l}\text { Pemeliharaan Tahap II } \\
\text { Stage // }\end{array}$} \\
\hline $\mathrm{A} 1$ & 451 & 380 & 428 \\
\hline A2 & 451 & 333 & 437 \\
\hline A3 & 256 & 394 & 412 \\
\hline
\end{tabular}

unsur hara bagi pertumbuhan rumput laut maupun bandeng.

Data pertambahan bobot bandeng selama penelitian pada setiap perlakuan disajikan pada Tabel 3. Pada awal pemeliharaan kisaran bobot dan panjang bandeng yang ditebar yaitu $3,44 \pm 1,83 \mathrm{~g}$ dan $4,78 \pm 0,62$ $\mathrm{cm}$. Setelah pemeliharaan 90 hari, pada masingmasing perlakuan diperoleh rata-rata bobot bandeng tersebut, yaitu perlakuan $A=20,63 \pm 5,25 \mathrm{~g}$, perlakuan
$\mathrm{B}=21,16 \pm 13,35 \mathrm{~g}$ dan perlakuan $\mathrm{C}=33,36 \pm 17,97 \mathrm{~g}$ Nilai rataan ketiga perlakuan tersebut tidak berbeda $(P>0,05)$. Berhubung karena ukuran bobot bandeng masih kecil dan memerlukan pemeliharaan lebih lanjut sampai pada tingkat konsumsi, maka nilai sintasan belum bisa disampaikan.

Nilai parameter kualitas air yang diamati dalam penelitian ini, yang meliputi: $\mathrm{DO}$, suhu, $\mathrm{pH}$, salinitas alkalinitas, BOT, $\mathrm{Fe}, \mathrm{SO}_{4}, \mathrm{NO}_{2}, \mathrm{NH}_{3}$, dan $\mathrm{PO}_{4}$

Tabel 3. Kisaran pertambahan bobot dan panjang bandeng, Chanos chanos pada padat tebar 500 ekor/ $2.500 \mathrm{~m}^{2} ; 1.000$ ekor $/ 2.500 \mathrm{~m}^{2}$; dan 1.500 ekor $/ 2.500 \mathrm{~m}^{2}$ selama penelitian

Table 3. Range of weight growth and length of milkfish, Chanos chanos with density of 500 individu/2,500 $\mathrm{m}^{2} ; 1,000$ individu/2,500 $\mathrm{m}^{2}$; and 1,500 individu/2,500 $\mathrm{m}^{2}$ during experiment

\begin{tabular}{|c|c|c|c|c|}
\hline $\begin{array}{c}\text { Waktu sampling (hari) } \\
\text { Observations (day) }\end{array}$ & $\begin{array}{l}\text { Parameter } \\
\text { Parameter }\end{array}$ & $\begin{array}{l}\text { Perlakuan A }(g) \\
\text { Treatment A }(g)\end{array}$ & $\begin{array}{l}\text { Perlakuan B }(\mathrm{g}) \\
\text { Treatment B }(g)\end{array}$ & $\begin{array}{l}\text { Perlakuan C }(g) \\
\text { Treatment } C(g)\end{array}$ \\
\hline \multirow{2}{*}{ Awal (Initial) } & Bobot (Weight) (g) & $3.44 \pm 1.83$ & $3.44 \pm 1.83$ & $3.44 \pm 1.83$ \\
\hline & Panjang (Length) (cm) & $4.78 \pm 0.62$ & $4.78 \pm 0.62$ & $4.78 \pm 0.62$ \\
\hline \multirow{2}{*}{15} & Bobot (Weight) (g) & $10.45 \pm 3.98$ & $7.13 \pm 3.34$ & $12.17 \pm 1.65$ \\
\hline & Panjang (Length) (cm) & $10.23 \pm 0.95$ & $9.03 \pm 1.65$ & $10.43 \pm 0.97$ \\
\hline \multirow{2}{*}{30} & Bobot (Weight) $(\mathrm{g})$ & $13.48 \pm 3.31$ & $11.73 \pm 3.58$ & $21.71 \pm 12.22$ \\
\hline & Panjang (Length) $(\mathrm{cm})$ & $11.74 \pm 1.06$ & $11.14 \pm 1.38$ & $13.07 \pm 1.49$ \\
\hline \multirow{2}{*}{45} & Bobot (Weight) (g) & $18.04 \pm 5.19$ & $16.33 \pm 7.86$ & $21.72 \pm 8.88$ \\
\hline & Panjang (Length) $(\mathrm{cm})$ & $12.75 \pm 1.26$ & $12.64 \pm 1.88$ & $13.52 \pm 2.19$ \\
\hline \multirow{2}{*}{60} & Bobot (Weight) $(\mathrm{g})$ & $14.83 \pm 3.12$ & $13.48 \pm 5.01$ & $19.68 \pm 7.71$ \\
\hline & Panjang (Length) (cm) & $13.57 \pm 0.77$ & $16.39 \pm 5.21$ & $13.58 \pm 1.87$ \\
\hline \multirow{2}{*}{75} & Bobot (Weight) (g) & $17.20 \pm 3.64$ & $15.72 \pm 9.89$ & $20.25 \pm 11.74$ \\
\hline & Panjang (Length) $(\mathrm{cm})$ & $12.57 \pm 0.93$ & $12.30 \pm 1.86$ & $13.32 \pm 2.34$ \\
\hline 90 & $\begin{array}{l}\text { Bobot (Weight) }(\mathrm{g}) \\
\text { Panjang }(\text { Length) }(\mathrm{cm})\end{array}$ & $\begin{array}{c}20.63^{\mathrm{a}} \pm 5.25 \\
13.48 \pm 1.19 \\
\end{array}$ & $\begin{array}{c}21.16^{a} \pm 13.35 \\
13.79 \pm 2.43\end{array}$ & $\begin{array}{c}33.36^{\mathrm{a}} \pm 17.97 \\
15.80 \pm 2.65\end{array}$ \\
\hline
\end{tabular}


diperlihatkan pada Tabel 4. Hasil pengamatan dari semua parameter kualitas ini masih dalam batas kelayakan bagi pertumbuhan rumput laut dan bandeng kecuali salinitas. Tingginya nilai salinitas disebabkan oleh waktu pelaksanaan penelitian yang bertepatan dengan musim kemarau dan lokasi penelitian kurang mendapat pasokan air tawar. Salinitas air yang mencapai tingkat $45 \mathrm{ppt}$ menyebabkan pertumbuhan rumput laut semakin lambat sehingga produksi yang diperoleh dalam penelitian ini tidak mencapai 1 ton setiap perlakuan. Berdasarkan hasil wawancara dengan bebera petani rumput laut di Kabupaten Sinjai, Takalar, dan Luwu menyatakan bahwa rumput laut dapat tumbuh dengan baik pada kisaran salinitas 10 - 20 permil. Largo et al. (1995) menjelaskan munculnya penyakit ice-ice pada budi daya Eucheuma apabila densitas cahaya kurang, salinitas kurang dari 20 0/ 00 , dan temperatur mencapai $33-35^{\circ} \mathrm{C}$. Selanjutnya menurut Mubarak et al. (1990) bahwa salinitas yang layak bagi pertumbuhan rumput laut, Gracillaria sp. di tambak adalah 18 - 30 ppt. Namun demikian, kemampuan rumput laut yang masih bisa tumbuh pada kisaran kadar garam sampai dengan 45 ppt dapat menjadi kajian lebih lanjut bagi pengembangan budidaya rumput laut Gracillaria sp. di tambak.

Nilai parameter kualitas tanah pada setiap perlakuan selama penelitian yang meliputi: $\mathrm{pH}$, Redox $\mathrm{mV}, \mathrm{pH}, \mathrm{PO}_{4}, \mathrm{P}_{2} \mathrm{O}_{5}, \mathrm{Fe}$, dan bahan organik disajikan dalam Tabel 5. Semua parameter kualitas tanah menunjukkan nilai yang masih berada pada kisaran yang layak untuk pertumbuhan rumput laut dan bandeng
Kisaran kandungan agar rumput laut yang diperoleh selama penelitian pada setiap perlakuan disajikan pada Tabel 6 .

Nilai rataan kandungan agar pada setiap perlakuan tidak berbeda $(P>0,05)$. Kandungan agar yang tidak berbeda menunjukkan bahwa kondisi lahan (tanah dan air) yang digunakan relatif homogen. Namun dari Tabel 6 tersebut diperoleh gambaran bahwa kandungan agar sebelum dan selama pemeliharaan mengalami penurunan. Penurunan ini menunjukkan bahwa kualitas lingkungan di tempat pengambilan bibit yaitu dari Kabupaten Luwu diduga memiliki karakteristik yang lebih mendukung kelayakan pemeliharaan rumput laut dibandingkan dengan lokasi penelitian. Mengantisipasi penurunan kandungan agar pada lahan yang memiliki kelayakan rendah, maka diharapkan pada masa yang akan datang suatu penelitian tentang penggunaan bahan input yang dapat merangsang pertumbuhan dan meningkatkan kandungan agar.

\section{KESIMPULAN}

Berdasarkan analisis dan pembahasan data penelitian polikultur rumput laut dengan bandeng dengan kepadatan yang berbeda, maka dapat disimpulkan bahwa produksi rumput laut Gracillaria $\mathrm{sp}$. dipengaruhi oleh padat tebar bandeng pada usaha budi daya secara polikultur dalam tambak. Penebaran bandeng sebanyak 500 ekor $/ 2.500 \mathrm{~m}^{2}$ memberikan produksi rumput laut terbaik $(440,33 \pm 30,57 \mathrm{~kg})$ dan secara statistik menunjukkan perbedaan yang nyata $(P<0,05)$. Pada musim kemarau, lahan tambak pada lokasi penelitian kurang layak untuk usaha budi daya

Tabel 4. Nilai kisaran parameter kualitas air dengan padat tebar bandeng, Chanos chanos 500 ekor/2.500 $\mathrm{m}^{2} ; 1.000$ ekor $/ 2.500 \mathrm{~m}^{2}$; dan 1.500 ekor $/ 2.500 \mathrm{~m}^{2}$ selama penelitian

Table 4. Range value of water quality with the density of milkfish, Chanos chanos 500 individu/2,500 $\mathrm{m}^{2}$; 1,000 individu $/ 2,500 \mathrm{~m}^{2}$; and 1,500 individu $/ 2,500 \mathrm{~m}^{2}$ during experiment

\begin{tabular}{llll}
\hline \multicolumn{1}{c}{$\begin{array}{c}\text { Parameter } \\
\text { Parameter }\end{array}$} & \multicolumn{1}{c}{$\begin{array}{l}\text { Perlakuan A }(\mathrm{g}) \\
\text { Treatment } A(g)\end{array}$} & $\begin{array}{l}\text { Perlakuan B }(\mathrm{g}) \\
\text { Treatment B }(\mathrm{g})\end{array}$ & $\begin{array}{l}\text { Perlakuan C }(\mathrm{g}) \\
\text { Treatment C }(\mathrm{g})\end{array}$ \\
\hline $\mathrm{DO}(\mathrm{mg} / \mathrm{L})$ & $3.94-4.98$ & $3.93-4.91$ & $3.73-5.34$ \\
$\mathrm{Suhu}($ Temperature $)\left({ }^{\circ} \mathrm{C}\right)$ & $27.03-29.70$ & $26.93-29.7$ & $26.97-29.50$ \\
$\mathrm{pH}$ & $7.50-8.17$ & $7.33-8.33$ & 7.508 .00 \\
Salinitas (Salinity) $(\mathrm{ppt})$ & $22.67-45.00$ & $22.67-45.00$ & $24.00-45.00$ \\
Alkalinitas (Alkalinity) $(\mathrm{mg} / \mathrm{L})$ & $11.93-162.67$ & $107.33-161.33$ & $108.87-166.67$ \\
$\mathrm{BOT}($ Total organic matter $)(\%)$ & $2.95-14.59$ & $2.65-9.29$ & $2.12-8.42$ \\
$\mathrm{Fe}(\mathrm{mg} / \mathrm{L})$ & $0.05-0.59$ & $0.05-0.56$ & $0.029-0.553$ \\
$\mathrm{SO}_{4}(\mathrm{mg} / \mathrm{L})$ & $10.82-150.16$ & $8.71-154.19$ & $9.104-141.05$ \\
$\mathrm{NO}_{2}(\mathrm{mg} / \mathrm{L})$ & $0.003-0.097$ & $0.003-0.101$ & $0.004-0.10$ \\
$\mathrm{NO}_{3}(\mathrm{mg} / \mathrm{L})$ & $0.005-1.471$ & $0.004-1.94$ & $0.0016-1.79$ \\
$\mathrm{NH}_{3}(\mathrm{mg} / \mathrm{L})$ & $0.001-0.936$ & $0.09-1.12$ & $0.071-1.091$ \\
$\mathrm{PO}_{4}(\mathrm{mg} / \mathrm{L})$ & $0.001-0.475$ & $0.004-0.591$ & $0.003-0.713$ \\
\hline
\end{tabular}


Tabel 5. Nilai parameter kualitas tanah pada padat tebar bandeng, Chanos chanos sebanyak 500 ekor/ $2.500 \mathrm{~m}^{2} ; 1.000$ ekor $/ 2.500 \mathrm{~m}^{2}$; dan 1.500 ekor $/ 2.500 \mathrm{~m}^{2}$ selama penelitian

Table 5. Value of soil quality on the density of milkfish, Chanos chanos 500 individu/2,500 $\mathrm{m}^{2} ; 1,000 \mathrm{individu/}$ $2,500 \mathrm{~m}^{2}$; and 1,500 individu/2,500 $\mathrm{m}^{2}$ during experiment

\begin{tabular}{lccccccc}
\hline $\begin{array}{c}\text { Parameter } \\
\text { Parameter }\end{array}$ & $\mathrm{pH}$ & $\begin{array}{c}\text { Redox } \\
\mathrm{mV}\end{array}$ & $\mathrm{pH}$ & $\mathrm{PO}_{4}$ & $\mathrm{P}_{2} \mathrm{O}_{5}$ & $\mathrm{Fe}$ & $\begin{array}{c}\mathrm{B.O} \\
(\%)\end{array}$ \\
\hline Perlakuan A & & & & & & & \\
Treatment $A$ & & & & & & & \\
Minimum (Minimum) & 6.72 & -405 & 0.5457 & 0.1558 & 17.8629 & 98.5 & 3.74 \\
Maksimum (Maximum) & 7.51 & -56 & 2.0116 & 1.5033 & 54.156 & 1416 & 25.36 \\
Rataan \pm StDev. & 7.04 & -193.86 & 0.69 & 0.51 & 43.56 & 530.67 & 10.59 \\
Average \pm StDev. & \pm 0.19 & \pm 118.97 & \pm 0.55 & \pm 0.41 & \pm 8.33 & \pm 373.26 & \pm 7.38 \\
\hline Perlakuan B & & & & & & & \\
Treatment B & & & & & & & \\
Minimum (Minimum) & 6.69 & -414 & 0.2331 & 0.1742 & 35.22 & 29.275 & 4.2 \\
Minimum (Minimum) & 7.47 & -94 & 1.6559 & 1.2375 & 63.624 & 1402 & 28.86 \\
Rataan \pm StDev. & 7.121 & -201.333 & 0.5718 & 0.4273 & 47.318 & 697.4417 & 11.5633 \\
Average \pm StDev & \pm .1891 & \pm 102.85 & \pm 0.464 & \pm 0.347 & \pm 6.8934 & \pm 440.41 & \pm 7.9350 \\
\hline Perlakuan C & & & & & & & \\
Treatment C & & & & & & & \\
Minimum (Minimum) & 6.56 & -388 & 0.2331 & 0.1742 & 34.431 & 130.25 & 3.11 \\
Maksimum (Maximum) & 7.47 & -77 & 2.0852 & 1.5583 & 53.367 & 1586.75 & 3.11 \\
Rataan \pm Standar deviasi & 7.095 & -208.286 & 0.663 & 0.4954 & 44.3499 & 753.4881 & 10.7133 \\
Average \pm otandart deviasi & \pm 0.2236 & \pm 99.8495 & \pm 0.4967 & \pm 0.3712 & \pm 4.6982 & \pm 520.527 & \pm 7.7739 \\
\hline
\end{tabular}

Tabel6. Nilai kandungan agar rumput laut, Gracillaria sp. dengan padat tebar bandeng, Chanos chanos

Table 6. Content of seaweedgel, Gracillaria sp. with the gelatine to density of milkfish, Chanos chanos 500 individu/2,500 $\mathrm{m}^{2} ; 1,000$ individu/2,500 $\mathrm{m}^{2}$; and 1,500 individu /2,500 $\mathrm{m}^{2}$ during experiment

\begin{tabular}{cccc}
\hline \multirow{2}{*}{$\begin{array}{c}\text { Waktu sampling (hari) } \\
\text { Observations (day) }\end{array}$} & \multicolumn{3}{c}{ Kandungan agar/ Content of gelatine (\%) } \\
\cline { 2 - 4 } & $\begin{array}{c}\text { Perlakuan A (g) } \\
\text { Treatment } \mathbf{A}(\mathbf{g})\end{array}$ & $\begin{array}{c}\text { Perlakuan } \mathbf{B}(\mathbf{g}) \\
\text { Treatment } \mathbf{B}(\mathbf{g})\end{array}$ & $\begin{array}{c}\text { Perlakuan C }(\mathbf{g}) \\
\text { Treatment } \mathbf{C}(\mathbf{g})\end{array}$ \\
\hline Awal (Initial) & 20.78 & 20.78 & 20.78 \\
15 & $19.15 \pm 3.16$ & $17.88 \pm 0.54$ & $15.37 \pm 1.94$ \\
30 & $14.57 \pm 3.38$ & $15.51 \pm 1.83$ & $14.46 \pm 3.68$ \\
45 & $16.64 \pm 3.05$ & $16.72 \pm 1.05$ & $16.17 \pm 3.16$ \\
60 & $16.91 \pm 6.24$ & $11.85 \pm 4.06$ & $16.37 \pm 0.51$ \\
75 & $16.21 \pm 0.30$ & $18.31 \pm 3.74$ & $18.28 \pm 1.97$ \\
90 & $15 \pm 0.8$ & $17.48 \pm 0.90$ & $16.73 \pm 1.64$ \\
\hline Rataan \pm standar deviasi & $17.63^{\mathrm{a}} \pm 2.42$ & $16.93^{\mathrm{a}} \pm 1.73$ & $16.87^{\mathrm{a}} \pm 1.84$ \\
\hline Average \pm otandart deviasi & & &
\end{tabular}

rumput laut karena salinitas yang sangat tinggi akibat kurangnya pasokan/sumber air tawar. Kandungan agar rumput laut menurun setelah pemeliharan, sehingga diperlukan penelitian lanjut tentang penambahan bahan input atau zat perangsang tumbuh yang dapat meningkatkan kandungan agar rumput laut.

\section{DAFTAR PUSTAKA}

Afrianto, E. dan E. Liviawaty, 1989. Budidaya Rumput Laut dan Cara Pengolahannya. Bhratara, Jakarta, $50 \mathrm{pp}$.

Aslan, L.M. 1995. Budidaya Rumput Laut. Penerbit Kanisius, $95 \mathrm{pp}$. 
Ditjen Perikanan Budidaya, 2004. Strategi pengembangan potensi rumput laut nasional untuk mendukung usaha pembudidayaan dan pengolahan hasil rumput laut. Makalah disampaikan pada Forum Rumput Laut Nasional di Mataram-NTB, 29 Juni-1 Juli 2004, 12 pp.

Largo, D.B., F. Fukami, T. Nishijima, and M. Ohno, 1995. Laboratory-induced development pf the ice-ice disease of the farmed red algae Kappaphycus alvarezii and Eucheuma denticulatum (Solieriaceae, Gigartinales, Rhodophyta). J.Appl. Phycol. (7):539543 .

Mubarak, H., S. Ilyas, W. Ismail, I. S. Wahyuni, S. T. Hartati, E. Pratiwi, Z. Jangkaru, dan R. Arifuddin. 1990. Petunjuk Teknis Budidaya Rumput Laut. Pusat Penelitian dan Pengembangan Perikanan, Badan Penelitian dan Pengembangan Pertanian. Departemen Pertanian, $93 \mathrm{pp}$.

Pantjara, B., S. Tahe, A. Mustafa, dan E.A. Hendradjat, 2003. Budidaya berbagai komoditas Bandeng, Chanos-chanos, Nila merah, Oreochromis niloticus, dan rumput laut, Gracillaria verrucosa di tanah tambak sulfat masam. Laporan hasil penelitian Balai Riset Perikanan Budidaya Air Payau. Tahun 2003, $23 \mathrm{pp}$

Ratnawati, E. dan A. Mustafa, 2003. Faktor pengelolaan yang berpengaruh terhadap produksi rumput laut, Gracillaria verrucosa di tambak tanah sulfat masam (Studi kasus di Kabupaten Luwu, Sulawesi Selatan). Laporan hasil penelitian Balai Riset Perikanan Budidaya Air Payau. Tahun 2003, 10 pp.
Saad, S., 2004. Prospek dan peluang pengembangan rumput laut. PT Bantumurung Indah (Bosowa Group). Makalah dismpaikan pada Workshop Budidaya Udang dan Rumput Laut di UPTD Balai Pembinaan dan Pengembangan Mekanisasi dan Perikanan Tangkap, pada tanggal 30 November 2004 di Makassar, $12 \mathrm{pp}$.

Sadhori, S.N., 1989. Budidaya Rumput Laut. Balai Pustaka. 110 pp

Soegiarto, A., Sulistijo, W.S. Atmadja, dan H. Mubarak, 1978. Rumput Laut (Algae), Manfaat, Potensi, dan usaha Budidayanya. LON-LIPI, $61 \mathrm{pp}$.

Sukmadinata, T., 2001. Peluang pemasaran rumput laut dan produk olahannya di pasar lokal dan ekspor. Laporan Forum Rumput laut, Pusat Riset Pengolahan Produk dan Sosial, Badan Riset Kelautan dan Perikanan, p. 37-56.

Susanto, A. B., dan A. Mucktiny, 2004. Studi kasus budidaya Gracillaria di Bekasi. Makalah disampaikan pada Forum Rumput Laut Nasional di Mataram-NTB, 29 Juni-1 Juli 2004. 10 pp.

Tjaronge, M. dan P.R. Pong-Masak, 2003. Budidaya rumput laut, Gracillaria sp. dengan sumber bibit dari daerah yang berbeda. Laporan Hasil Penelitian Balai Riset Perikanan Budidaya Air Payau. Tahun 2003, $11 \mathrm{pp}$.

Wong, K.H. and K.P.C. Cheung, 2000. Nutritional evaluation of some subropical red and green seaweeds: part 11 - In vitro protein digestibelity and amino acid profiles of protein concentrates. Food Chemistry, 72:11-17. 
